\title{
Development of a Polyethylene Mulch System that Changes Color in the Field
}

\author{
Heather A. Hatt Graham \\ Plant Sciences Department, New Mexico State University, Las Cruces, \\ NM 88003
}

Dennis R. Decoteau ${ }^{1}$

Department of Horticulture, Box 340375, Clemson University, Clemson, SC 29634-0375

\author{
Dale E. Linvill \\ Department of Agricultural and Biological Engineering, Clemson University, \\ Clemson, SC 29634-0375
}

Additional index words. Lycopersicon esculentum, Cucurbita pepo, soil temperature, photodegradation

Abstract. A polyethylene mulch system that changes its predominant surface color from black to white in the field has been developed and used to grow tomatoes (Lycopersicon esculentum Mill. cv. Mountain Pride) and squash [Cucurbita pepo var. melopepo (L.) Alef. cv. Dixie Hybrid]. The system uses a black photodegradable polyethylene mulch placed on top of a white nondegradable polyethylene mulch (photodegradable mulch overlay system). As the black photodegradable mulch degrades with increasing exposure to radiation, the white mulch surface is exposed. Differences among plastic systems in the percentage that breaks down may be explained by differential shading of the mulch by the vegetative growth of the crops. None of the formulations of the Plastigone brand photodegradable mulches in the photodegradable mulch overlay system had an effect on tomato or squash production. As the color of the system changed from black to white, soil temperatures under the mulch decreased. Tomato production remained unaffected in one of the two years as long as the mulch remained black for at least the first $\mathbf{2 0}$ days during that season. In year 2, the controlled mulch system color change affected neither tomato nor squash production relative to nondegradable white and black mulches used as controls.

Spring-planted fresh-market tomatoes and summer squash often are grown with a black polyethylene mulch cover on the soil. Black mulch benefits early plant production by conserving moisture (Bhella, 1988; Jones et al., 1977; Sweeney et al., 1987) and fertilizer (Bhella, 1988; Jones et al., 1977; Wien and Minotti, 1987), retarding weeds (Smith, 1968), and resulting in warming the roots (Taber, 1983). The black mulch absorbs most of the ultraviolet (UV), visible, and infrared portions of the solar spectrum and also radiates energy as heat (Ham et al., 1993; Hatt et al., 1993). We have observed extreme heat buildup under a black mulch in South Carolina during sunny days in the mid to late summer that killed or

Received for publication 6 June 1994. Accepted for publication 3 Nov. 1994. Technical Contribution no. 3344 of the South Carolina Agricultural Experiment Station, Clemson Univ. This research was supported in part by Experiment Station Project no. 1187 and a U.S. Dept. of Agriculture Special Grant P.L. 89-106. No endorsement of the products named is implied by Clemson Univ. or the South Carolina Experiment Station. We thank Jim Harris, Glen Christian, and Anthony Melton for technical sup port. The cost of publishing this paper was defrayed in part by the payment of page charges. Under posta regulations, this paper therefore must be hereby marked advertisement solely to indicate this fact.

${ }^{1}$ To whom reprint requests should be addressed. stunted the growth of many crops, including tomatoes. This problem often limits the use of the black plastic for double-cropping with a fall-planted crop following a spring-planted crop. Because of this heat buildup, a whitesurfaced mulch is often recommended for use in the southern United States during the summer and fall (Cook et al., 1982; Lamont, 1993; Schalk and Robbins, 1987). A white mulch does not warm the soil as much as a black mulch because the white surface reflects most of the wavelengths of solar radiation (Decoteau et al., 1989; Hatt et al., 1993). Methods currently used to apply paint to change the color of the mulch in the field include using a sprayer, paint brush (roller or bristle), or a household mop. None of these methods is applicable to large acreages. An alternative method of changing the color of the mulch in the field is to remove the mulch and replace it with a mulch of a different color. This method is costly and labor- and equipment-intensive.

Mulches are available that photodegrade relatively early or late in the season (Decoteau and Rhodes, 1990). When these mulches break down, the underlying soil surface is exposed. A photodegradable mulch overlay system that uses a black photodegradable mulch placed on top of a white nondegradable mulch has been developed. As the black photodegradable mulch degrades with increasing exposure to radiation, the white nondegradable mulch is exposed, thereby changing the predominant color of the exposed surface from black to white. The type and formulation of photodegradable plastic chosen for the system could provide some control on the timing of the mulch color change.

The objectives of this study were 1) to determine the effectiveness of the photodegradable mulch overlay system (photodegradable black mulch placed on top of white nondegradable mulch) as a method for changing the predominant surface color of mulch from black to white; 2) to monitor soil temperatures under the mulch as the white mulch becomes exposed during the season; and 3) to determine the influence of a mulch color change from black to white during the growing season on the production of fresh-market tomatoes and squash.

\section{Materials and Methods}

The effectiveness of the photodegradable mulch overlay system (MOS) that changes surface color in the field with season was determined. In addition, the influence of this system on fresh-market tomato and summer squash production was evaluated at the Clemson Univ. Calhoun Field Site in Clemson, S.C. Tomato and squash were chosen because they represent relatively long-season and shortseason crops, respectively. The soil was a Congaree silt loam (Typic Paleudults). Fertilizer was applied at N, P, and $\mathrm{K}$ rates of 84,112 ,

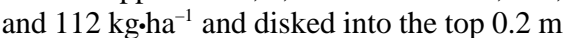
of soil before bed preparation, application of mulch, and planting.

Photodegradable MOS. White nondegradable polyethylene mulch ( $1.5 \mathrm{~m}$ wide and 0.03 $\mathrm{mm}$ thick), trickle irrigation tubing, and methyl bromide fumigation (at a rate of 280 $\mathrm{kg} \cdot \mathrm{ha}^{-1}$ ) were applied to all plots by machine on 22 May 1989 and 15 May 1990. The polyethylene-mulched beds were $0.8 \mathrm{~m}$ wide and $0.1 \mathrm{~m}$ high. Photodegradable mulch overlay plots were established by placing various formulations of Plastigone brand photodegradable plastic ( $1.5 \mathrm{~m}$ wide and $0.03 \mathrm{~mm}$ thick) (Ideamasters, Miami) on top of the white plastic. The formulations of mulch were chosen to evaluate relatively early (Plastigone 221B, Plastigone 2B) and late-season (Plastigone 131B, Plastigone 19B) degrading mulches. These mulches were monitored for rapidity and extent of mulch color change, soil temperatures under the mulch, and yield of freshmarket tomato and squash. White nondegradable polyethylene without a mulch overlay and black nonphotodegradable polyethylene overlaid on white polyethylene served as season-long white and black mulch controls, respectively.

Controlled mulch color change. To determine the effects of a controlled mulch color change from black to white on tomato (1989 and 1990) and squash (1990) production, a separate experiment was conducted painting the entire exposed surface of black polyethylene mulch (that had been previously applied to the field) with a white enamel paint (\#211A- 
117, Ace Hardware Porch and Floor Enamel, Oak Brook, Ill.) at various times during the season. Fertilizer, black polyethylene mulch, trickle irrigation, and methyl bromide fumigation were applied in a similar manner and on the same date as in the MOS experiment described above. Experimental plots were established by painting black mulch white 2, 20,40, 60 , and 80 days after planting (DAP). Control plots were not painted white and remained black the entire season.

Mulch treatments in the MOS and the controlled mulch color change experiments were arranged in a randomized complete-block design with four replications per treatment. Plots were $6.1 \mathrm{~m}$ long with rows $1.8 \mathrm{~m}$ apart; one replication of the mulch treatments was not planted. Soil temperatures were measured with a Campbell CR21X Datalogger (Campbell, Logan, Utah) equipped with copper-constantan thermocouples. Thermocouples were placed $2.5 \mathrm{~cm}$ below the mulch in nonplanted plots in 1989 and 1990 and in tomato-planted plots in 1990. In each plot, three thermocouples spread $0.7 \mathrm{~m}$ apart along the center of the bed were connected in parallel to minimize effects of slight variation in either depth placement of the thermocouple or soil property on soil temperature.

Six-week-old tomato seedlings were transplanted for both experiments, on 5 June 1989 and 21 May 1990, at an in-row spacing of 0.6 $\mathrm{m}$. Tomatoes were transplanted at a later date in 1989 than in 1990 because a wet spring delayed final field preparation in 1989. This delay in transplanting in 1989 also resulted in a later fruit harvest in 1989 than in 1990 . Fiveweek-old squash seedlings were transplanted for both experiments on 21 May 1990 at an inrow spacing of $0.9 \mathrm{~m}$. Recommended cultural practices for commercial tomato production (including staking and pruning) (Cook et al., 1982) and squash production (Cook et al., 1978) were followed throughout the study.

The MOS plots were visually rated once a week throughout the growing season for percent breakdown (expressed as percentage of exposed white mulch) as an indication of system color change from black to white. Tomato fruit at a breaker stage were harvested in both experiments, once a week, beginning on 10 Aug. 1989 and 18 July 1990. Marketable yield consisted of tomato fruit graded US no. 1 or US no. 2 (U.S. Dept. of Agriculture Agricultural Marketing Service, 1976). Squash fruit harvest began on 12 June 1990 with marketable fruit harvested an average of three times a week. Early yield consisted of the cumulative amount of fruit harvested during the first three weeks of harvest.

\section{Results and Discussion}

Photodegradable MOS. The chemical formulation of photodegradable mulch in the overlay system affected the rate and degree of mulch color change from black to white during the season in 1989 (Fig. $1 \mathrm{~A}$ and B) and 1990 (Fig. 2A-C). In nonplanted plots (Figs. $1 \mathrm{~A}$ and $2 \mathrm{~A}$ ), all of the Plastigone MOS evaluated had $>90 \%$ mulch color change by the end

\section{FIG. 1, LINE ART SHOOT at $50 \%$}

\section{DROP KEYLINE}

Fig. 1. Influence of formulation of Plastigone black photodegradable mulch placed on top of a white nondegradable mulch on mulch color change from black to white during the 1989 season in plots that were $(\mathbf{A})$ not planted and $(\mathbf{B})$ planted with tomatoes. Values are means $(\mathrm{n}=1)$ in Fig. $1 \mathrm{~A}$ and means $\pm \mathrm{sE}$ $(n=3)$ in Fig. 1B.

\section{FIG. 2, LINE ART SHOOT at $50 \%$}

\section{DROP KEYLINE}


of the season each year. The $221 \mathrm{~B}$ and the $2 \mathrm{~B}$ MOS had $>90 \%$ mulch color change by 9 July 1989 and 5 July 1990 ; the change was $100 \%$ by 26 July 1989 and 7 July 1990 . The 131B MOS had $>90 \%$ mulch color change by 31 Aug. 1989 and 11 July 1990.

The breakdown characteristics of the photodegradable mulch were similar to the characteristics previously described for several of the Plastigone materials (Decoteau and Rhodes, 1990) and consisted initially of splitting the mulch originating from the holes where the transplants were placed. With increased exposure to solar radiation, splitting and tearing of the black mulch increased and sections of it were windblown out of the plots. This mechanical damage and removal of the black photodegradable mulch resulted in increased exposure of the white nondegradable plastic (Fig. 3).

In plots planted with tomatoes (Figs. 1B and 2B), the 221B MOS began to photodegrade the earliest, with white mulch visible by 26 June 1989 and 18 June 1990. The 221B MOS had almost completely changed color to white by 26 July 1989 and 25 July $1990(\approx 9$ weeks after mulch application). The 2B MOS had changed color by 20 July 1989 and 5 July 1990. The differences in the rate of breakdown of the photodegradable mulches between the planted and nonplanted plots suggest that the amount of foliage covering the photodegradable polyethylene affected the degree of exposure of the mulch to light, which affected rate of degradation and resulting mulch color change.

In plots planted with squash (Fig. 2C) in 1990 , the $221 \mathrm{~B}$ MOS had changed $\approx 90 \%$ by the end of the season. The $2 \mathrm{~B}$ MOS had $\approx 30 \%$ mulch color change, and the 131B MOS had $<5 \%$ color change by the end of the season. Color change was less for the $2 \mathrm{~B}$ and the $131 \mathrm{~B}$ MOS in these plots than in those planted with tomatoes and not planted by the end of the season in 1990. These differences in percent breakdown in systems among crops may be explained by shading of the mulch by the vegetative growth of the crops. The dense growth of squash shaded more of the mulch earlier than did tomato. Shading by the vegetation appears to reduce the amount of UV radiation absorbed by the photodegradable mulches and slows the degradation rate. In 1989 and 1990, the formulation of the mulch used in the MOS had no effect on total marketable yield of tomato or squash (data not presented: coefficients of variation for total marketable yield of tomato were 12.7 and 14.5 in the 1989 and 1990 evaluations, respectively; and coefficient of variation for total marketable yield of squash was 10.3 in 1990).

The daily maximum soil temperatures recorded under the plastic systems in the nonplanted plots in 1989 (Fig. 4A) and 1990 (Fig. 4B) and in those tomato-planted in 1990 (Fig. 4C) were affected by the day on which temperatures were monitored and the mulch system. The days on which maximum soil temperatures (as averaged across all mulch systems) were low (e.g., 2 July, 15 July, 20 July, and 8 Aug. in 1989; and 14 July and 20

\section{FIG. 3, HALFTONE} SHOOT at $64 \%$

\section{DROP KEYLINE}

Fig. 3. Breakdown of the photodegradable black mulch exposing white nondegradable mulch beneath, thereby changing the exposed surface of the mulch system from black to white.

\section{FIG. 4, LINE ART SHOOT at $51 \%$}

\section{DROP KEYLINE}

Fig. 4. Influence of formulation of Plastigone black photodegradable mulch placed on top of a white nondegradable mulch on maximum hourly soil temperatures recorded $2.5 \mathrm{~cm}$ under the mulch during the 1989 season in plots that were (A) not planted and during the 1990 season in plots that were (B) not planted and $(\mathbf{C})$ planted with tomatoes. 
July in 1990) corresponded to days on which precipitation was recorded (Fig. 5). The amount of solar radiation reaching the mulch during these days was probably low because of cloud cover associated with the precipitation. Days on which maximum soil temperatures were high were also those with little to no precipitation; therefore, solar energy reaching the mulch was probably high. Soil temperatures in the tomato-planted plots were lower than in the corresponding nonplanted plots in 1990, probably due to shading of the mulch by the tomato plant foliage.

For both years, daily maximum soil temperatures (as averaged across all monitoring dates) were lower under the white mulch than under any of the MOS. Of the MOS, 221B had the lowest average daily maximum temperature and 131B had the highest.

Color change in the MOS occurs over several days; therefore, soil temperature, as a consequence of color change, changes gradually. In general, maximum soil temperatures under the MOS were similar to those under the white mulch when $>80 \%$ had changed from black to white (Fig. 6). For example, at the beginning of the season in 1990, soil temperatures in nonplanted plots under 221B were $\approx 7 \mathrm{C}$ higher than under the white control. By 24 June, when $>80 \%$ had changed from black to white with $221 \mathrm{~B}$, soil temperatures in the nonplanted plots were similar to those under the 221B.

Controlled mulch color change system. The amount of time that the mulch was black in the beginning of the season affected tomato production in the controlled MOS color-change experiment in 1989 (Table 1) but not in 1990 (data not presented: coefficient of variation for total marketable yield of tomato was 12.0). The amount of yield (early and total), number of fruit, and percentage of marketable tomato fruit by the end of the harvest in 1989 were the least from plots that had been painted white 2 days after transplanting. Early yield was similar for plots when black mulch was painted white $20,40,60$, or 80 DAP. Of these treatments, only the 40 DAP plots differed in early yield from those with season-long black mulch. Total marketable yield was similar for the black mulch control and for the 20,40,60, and 80 DAP treatments. These results suggest that as long as the mulch remained black for at least 20 days in 1989, mulch color change from black to white did not influence tomato production. Mulch color change had no effect on squash production in 1990 (data not presented: coefficient of variation for total marketable yield of squash was 10.1).

Color change in the controlled MOS occurred almost immediately (at the time of painting of the mulch); therefore, changes in soil temperature under this system as a result of color change occurred more quickly than under the MOS. In general, when white paint was applied to the black mulch, maximum soil temperatures reached temperatures recorded under plots painted earlier in $\approx 3$ days. There were fewer differences in soil temperatures among the treatments in the planted plots (Fig. 6C).

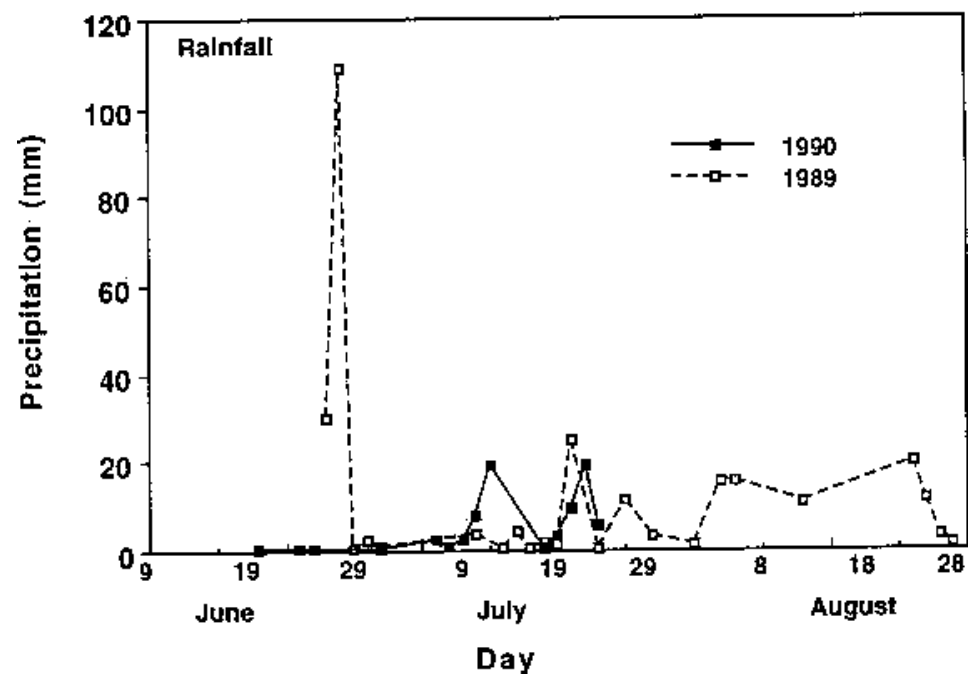

Fig. 5. Precipitation recorded during the 1989 and 1990 growing seasons.

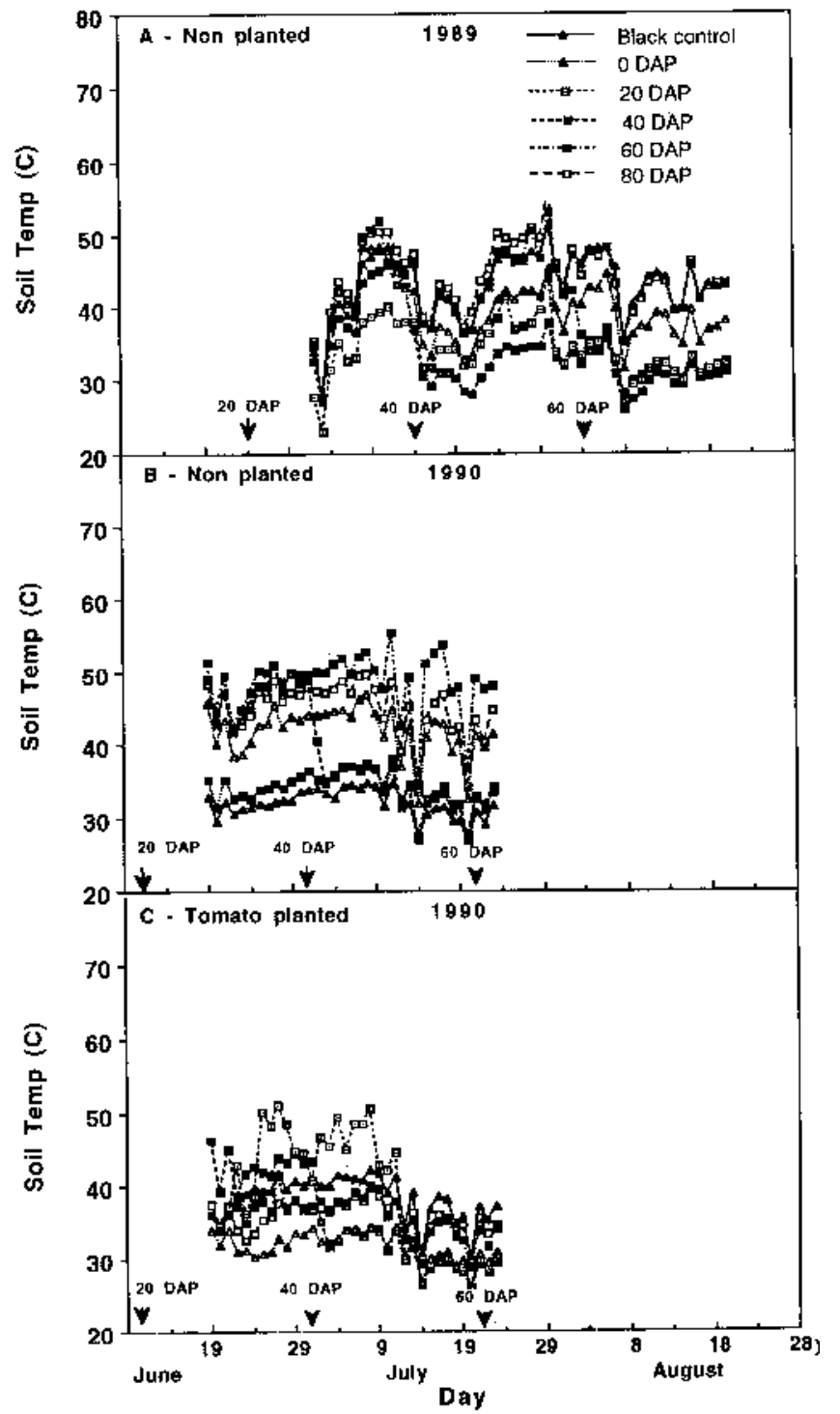

Fig. 6. The influence of painting black polyethylene white at various times during the season on maximum hourly soil temperatures recorded $2.5 \mathrm{~cm}$ under the mulch during the 1989 season in plots that were (A) not planted and during the 1990 season in plots that were $(\mathbf{B})$ not planted and $(\mathbf{C})$ planted with tomatoes. 
Table 1. Effects of timing of controlled mulch color change on tomato production in 1989.

\begin{tabular}{|c|c|c|c|c|c|}
\hline \multirow{2}{*}{$\begin{array}{l}\text { Time when } \\
\text { painted } \\
(\mathrm{DAP})^{\mathrm{z}}\end{array}$} & \multicolumn{2}{|c|}{$\begin{array}{c}\text { Marketable yield } \\
\left(\mathrm{t} \cdot \mathrm{ha}^{-1}\right)\end{array}$} & \multirow{2}{*}{$\begin{array}{l}\text { No. fruit/ha } \\
(\times 1000)\end{array}$} & \multirow{2}{*}{$\begin{array}{c}\text { Mean fruit wt } \\
\text { (g) }\end{array}$} & \multirow{2}{*}{$\begin{array}{c}\text { Marketable fruit } \\
\qquad(\%)\end{array}$} \\
\hline & Early & Total & & & \\
\hline Never & $22.8 \mathrm{a}^{\mathrm{y}}$ & $53.1 \mathrm{a}$ & $202 a$ & 262.9 & $81.0 \mathrm{a}$ \\
\hline 2 & $15.1 \mathrm{c}$ & $45.7 \mathrm{~b}$ & $172 b$ & 265.6 & $77.4 \mathrm{~b}$ \\
\hline 20 & $21.6 \mathrm{ab}$ & $55.1 \mathrm{a}$ & $218 \mathrm{a}$ & 253.3 & $81.2 \mathrm{a}$ \\
\hline 40 & $18.9 \mathrm{~b}$ & $55.1 \mathrm{a}$ & $213 \mathrm{a}$ & 258.3 & $81.4 \mathrm{a}$ \\
\hline 60 & $21.8 \mathrm{ab}$ & $52.8 \mathrm{a}$ & $213 a$ & 248.3 & $80.6 \mathrm{a}$ \\
\hline 80 & $19.7 \mathrm{ab}$ & $56.1 \mathrm{a}$ & $221 \mathrm{a}$ & 253.8 & $80.5 \mathrm{a}$ \\
\hline Significance & $*$ & $*$ & $*$ & NS & $*$ \\
\hline $\begin{array}{l}\text { Coefficient of } \\
\text { variation }\end{array}$ & 9.2 & 10.0 & 11.2 & 9.8 & 8.8 \\
\hline
\end{tabular}

${ }^{2} \mathrm{DAP}=$ days after planting of tomatoes that the black plastic was painted white.

${ }^{y}$ Mean separation within columns by LSD, $P \leq 0.05$.

Ns, *Nonsignificant or significant at $P \leq 0.05$, respectively.

\section{Conclusions}

Our results suggest that the photodegradable MOS can be used when a mulch color change with time in the field is desired. This system would be beneficial in double-cropping where the same mulch is used for both spring and fall crops (such as bell peppers planted in the spring followed by squash planted in late summer). The mulch system could also be used with long-season spring or summerplanted crops (such as tomatoes), where use of black mulch later in the season would result in high root-zone temperatures that may adversely affect crop production. The photodegradable MOS effectively changed color from black to white with increasing time in the field. This change in surface color affected soil temperatures recorded under the mulch. Differences in soil temperatures between plots with black mulch and plots that had predominantly whitesurfaced mulch were similar to those previously reported by Decoteau et al. (1989) and Ham et al. (1993).

Photodegradable mulch type and formulation affected the rate and thoroughness of mulch color change. Several mulch color changes during the season might be accomplished by having more than one layer of differently pigmented photodegradable plas- tic on top of the nondegradable mulch. A coextruded prototype of a photodegradable black surface on a photodegradable white surface was produced by a commercial manufacturer and evaluated in our plots in 1990 (data not presented). The white photodegradable undersurface degraded soon after or at the same time as the black photodegradable upper surface, thereby limiting its usefulness in a mulch color-change system. Future research should test the effectiveness of a coextruded black photodegradable surface on a white nondegradable surface for use in a system when a mulch color change from black to white is desired. Also, we suspect that the effectiveness and rate of color change of the photodegradable MOS will be influenced by other factors that affect the amount of sunlight reaching the photodegradable surface such as season, location, and row orientation. The costs associated with using the photodegradable MOS for high-value cash crops such as tomatoes must be determined before commercial applications can be recommended.

\section{Literature Cited}

Bhella, H.S. 1988. Tomato response to trickle irrigation and black polyethylene mulch. J. Amer. Soc. Hort. Sci. 113:543-546.

Cook, W.P., D.O. Ezell, R.P. Griffin, C.E. Drye, and
P.J. Rathwell. 1982. Commercial tomato production in South Carolina. Clemson Univ. Coop. Ext. Serv. Circ. 625.

Cook, W.P., D.O. Ezell, F.H. Smith, and R.P. Griffin. 1978. Commercial squash production. Clemson Univ. Veg. Leaflet 14.

Decoteau, D.R., M.J. Kasperbauer, and P.G. Hunt. 1989. Mulch surface color affects yield of freshmarket tomatoes. J. Amer. Soc. Hort. Sci. 114:216-220.

Decoteau, D.R. and B.B. Rhodes. 1990. Characteristics and effectiveness of photodegradable mulch in watermelon production. Appl. Agr. Res. 5:9-12.

Ham, J.M., G.J. Kluitenberg, and W.J. Lamont. 1993. Optical properties of plastic mulch affect the field temperature regime. J. Amer. Soc. Hort. Sci. 118:188-193.

Hatt, H.A., M.J. McMahon, D.E. Linvill, and D.R. Decoteau. 1993. Influence of spectral qualities of mulch film on bell pepper growth and production. Proc. Natl. Agr. Plastics Congr. 24:233239.

Jones, T.L., U.S. Jones, and D.O. Ezell. 1977. Effect of nitrogen and plastic mulch on properties of Troup loamy sand and yield of 'Walter' tomatoes. J. Amer. Soc. Hort. Sci. 102:273-275.

Lamont, W.J. 1993. Color your decision. Amer. Veg. Grower November, p. 22-24.

Schalk, J.M. and M.L. Robbins. 1987. Reflective film mulches influence plant survival, production, and insect control in fall tomatoes. HortScience 22:30-32.

Smith, D.F. 1968. Mulching systems and techniques. Proc. Natl. Agr. Plastics Conf. 8:112-118.

Sweeney, D.W., D.A. Graetz, A.B. Bottcher, S.L. Locascio, and K.L. Campbell. 1987. Tomato yield and nitrogen recovery as influenced by irrigation method, nitrogen source, and mulch. HortScience 22:27-29.

Taber, H.G. 1983. Effects of plastic soil and plant covers on Iowa tomato and muskmelon production. Proc. Natl. Agr. Plastics Conf. 17:37-45.

U.S. Department of Agriculture Agricultural Marketing Service. 1976. U.S. standards for grades of fresh market tomatoes. U.S. Dept. Agr., Agr. Mktg. Serv., Washington, D.C.

Wien, H.C. and P.L. Minotti. 1987. Growth, yield, and nutrient uptake of transplanted fresh-market tomatoes as affected by plastic mulch and initial nitrogen rate. J. Amer. Soc. Hort. Sci. 112:759-763. 